\title{
Os usos do perfil - formas de ensino e práticas da diferença em escolas de teatro musical
}

\author{
BERNARDO FONSECA MACHADO \\ UNIVERSIDADE ESTADUAL DE CAMPINAS (UNICAMP), CAMPINAS/SP, BRASIL \\ HTTPS://ORCID.ORG/0000-00OI-8884-2357
}

No processo de formação para a carreira de ator/atriz, estudantes de teatro aprendem como apresentar uma personagem - ensaiam gestos e lapidam vozes. Em exercícios de interpretação, emergem os tropos que informam como seria a caracterização de um "vilão", as posturas de uma "princesa”, os trejeitos de uma "prostituta" e assim por diante. Igualmente sugere-se que certos corpos são mais adequados para colocar na cena determinado papel — nem todo mundo tem "perfil" para protagonista. Mobiliza-se continuamente, em salas de aula, repertórios de gênero, raça, classe e sexualidade forjados social e historicamente. Tal ambiente de aprendizado, portanto, oferece à antropologia um campo singular para discutir a relação intrincada entre corpos, práticas da diferença e formas de desigualdade. Todos os corpos podem realizar todos os papéis?

Este artigo $^{1}$ descreve aulas das disciplinas de "audição" de duas escolas de teatro musical — uma em São Paulo e outra em Nova York. Entre 2015 e 2016, realizei pesquisa de campo em diversos ambientes cênicos, dentre eles instituições de ensino. Nessas ocasiões, notei como o aprendizado atualizava noções normativas de gênero, sexualidade e raça no cotidiano de trabalho. Professores estimulavam estudantes a reconhecer seu "perfil", isto é, identificar o formato físico (altura, peso e silhueta), a cor/ raça, os traços no rosto e até a própria personalidade; somente assim se tornariam aptas/os para disputar um papel no mercado de trabalho.

O trabalho se insere em dois grandes universos de pesquisa. Em primeiro lugar, inspira-se na expansão dos debates sobre antropologia da educação e/ou antropologia e educação (Tosta 2013; Gus-

1 Este texto é uma versão aprimorada e enxuta do capítulo 4 de minha tese de doutorado denominada Atos da Diferença: trânsitos teatrais entre São Paulo e Nova York no início do século XXI, defendida no PPGAS/USP em 2018 sob orientação da Profa. Lilia Schwarcz e financiada pela Fapesp ( $\mathrm{n}^{\circ}$ do processo 2014/15902-2). Estas reflexões continuam em minha pesquisa de pós-doutorado - financiado pela Fapesp ( $\mathrm{n}^{\circ}$ do processo 2019/08713-2) - na qual investigo como os corpos de artistas são qualificados em termos de gênero, raça e sexualidade com base nas ideias de "verdade cênica" e de "representatividade". 
mão 2015; Dauster 2015; Pereira 2017). Dialogo, especificamente, com as pesquisas interessadas em esmiuçar os processos de produção da diferença em ambientes educacionais (Gomes 2005; Junqueira 2010; Escoura 2012; Miranda e Maia 2017; Alegria 2018; Macedo 2019). Um conjunto de trabalhos antropológicos realizados em escolas de teatro serviu igualmente de referência e baliza para avançar nas análises (Coelho 1989; Ribeiro 2008; Araújo 2009; Peres 2013). Em segundo lugar, descrevo as práticas da diferença em disputa, isto é, atino para os referenciais que informam como corpos são lidos, silenciados e tratados. A proposta deste artigo sintoniza com uma antropologia que estuda a produção da diferença a partir da chave da interseccção de marcas sociais (Crenshaw 1991; Piscitelli 2008; Brah 2006; Moutinho 2014). Particularmente em relação aos corpos de profissionais do campo do entretenimento, há textos que apostaram no exame da relação entre a trajetória artística, a apresentação física e as convenções estéticas (Pontes 2010; Hirano 2013; César 2018; Sobral 2015).

$\mathrm{O}$ espaço pedagógico teatral insere um conjunto de desafios teóricos e metodológicos. Em primeiro lugar, em escolas para atrizes e atores, especialmente de musicais, um conjunto específico de disciplinas, de técnicas e de convenções estéticas exige da análise a lida com repertórios muitas vezes distantes dos paradigmas pedagógicos convencionais. Em segundo lugar, as próprias noções de "diferença" e de "alteridade" assumem contornos semânticos específicos e variados. No caso das escolas de teatro musical em que pesquisei, o interesse pela alteridade se materializava em paradigmas estéticos, isto é, como "representar o outro" - a personagem - via o próprio corpo.

O texto pretende, de um lado, adensar a discussão sobre um ambiente pedagógico ainda pouco explorado pela literatura antropológica: as escolas de teatro. De outro, compreender como esses processos pedagógicos produziam corpos. Partindo do pressuposto de que toda forma de aprendizagem é situada (Lave 2015), apresentarei alguns dos procedimentos de ensino mobilizados por docentes e discentes nesses ambientes de teatro musical e como eles resultavam em processos de naturalização de diferenças.

Para analisar esse universo, optei por perseguir os usos do termo perfil nas salas de aula e nas falas de docentes e de estudantes de teatro. Ao selecionar uma categoria para discussão, procuro compreender o universo de significados que ela aciona e produz. Alguns trabalhos investigaram justamente os sentidos de determinadas palavras e suas potencialidades semânticas. Manuela Carneiro da Cunha (2009), por exemplo, examinou as disputas em torno da palavra "cultura" em algumas etnias indígenas. Bazzo (2017a), por sua vez, esmiuçou como a categoria bullying comunicava sensibilidades sobre violência, sofrimento e reparação em ambientes escolares. Com essas inspirações, parto do pressuposto de que só será possível entender os usos da palavra perfil tomando a categoria de forma relacional, como prática construída com efeitos materiais. A análise atenta do termo confere acesso a um campo de referências e de ações que afetam os horizontes do dizível e do visível.

Começo o texto apresentando brevemente os desafios metodológicos envolvidos, as duas instituições de ensino analisadas e as particularidades da disciplina audição. Nas seções seguintes, descrevo como se davam os processos de aprendizado da convenção de perfll: as instruções empregadas, os exercícios escolhidos e o tom adotado por docentes. Discuto, ao final, como a categoria perfil se embrenha, via recursos de ensino, nas práticas e nos corpos de estudantes. 


\section{Considerações metodológicas}

Na virada do século XX para o XXI, espetáculos musicais da Broadway passaram a ser apresentados em dezenas de países, materializados pelos corpos de artistas nacionais. Esse sistema teatral foi resultado de um planejamento político-econômico para a internacionalização dessa estética e de uma prática de expansão de referenciais estadunidenses pelo globo (Machado 2018, 2020b). No Brasil, particularmente em São Paulo, condições legislativas, interesses empresariais e o fascínio de parcela da classe artística se combinaram e tornaram possível a abundante aterrissagem desses espetáculos no país. Como efeito, dezenas de peças do teatro musical dos Estados Unidos passaram a ser encenadas por corpos brasileiros, tornando-se parte da agenda cultural de muitas capitais. Nesse contexto, foram fundadas algumas instituições de ensino dedicadas a formar artistas especializados nessa modalidade estética específica. Empresários vislumbraram uma fatia de mercado e uma demanda por profissionalização.

Em trabalhos anteriores pude explorar os repertórios teatrais em trânsito entre os países, analisando os objetivos comerciais de produtores brasileiros e estadunidenses, as peças encenadas em cada cidade, as técnicas de interpretação adotadas nos dois contextos e também a migração de artistas brasileiros para os Estados Unidos com o objetivo de trabalharem no mercado de entretenimento (Machado 2018, 2020a). Neste artigo, como já foi mencionado, meu foco de análise recai numa disciplina de nome similar em ambos os contextos pesquisados: Audição, no caso do Brasil, e Audition technique, nos Estados Unidos. Além da proximidade nominal, os objetivos e os métodos ensinados eram similares - a grade de disciplinas, o conteúdo das aulas e algumas das técnicas abordadas - isso porque os fundadores da instituição paulistana se inspiraram naquelas estadunidenses para desenharem o formato da escola.

No caso nacional, realizei pesquisa de campo numa escola paulistana criada em 2009 dedicada à profissionalização de artistas para esse tipo específico de teatro ${ }^{2}$. O prédio, localizado na Zona Sul de São Paulo, tinha três andares e havia sido ocupado anteriormente por uma faculdade privada. Na adaptação, os pisos de madeira foram mantidos e grandes espelhos instalados nas salas de aula. Em 2015, a mensalidade rondava $\mathrm{R} \$ 630,00$ e correspondia a 71,6\% do salário mínimo federal (fixado em $\mathrm{R} \$$ 880,00 ) e $63 \%$ do salário mínimo paulista (definido em R \$1.000,00). Acompanhei, ao longo do primeiro semestre de 2015, as aulas de uma das turmas formada por 7 jovens mulheres entre 20 e 25 anos.

Já a pesquisa em Nova York ocorreu em um estabelecimento de ensino fundado em 1992 por um produtor de entretenimento. Na ilha de Manhattan, o espaço detinha cerca de 20 salas de aula, todas equipadas com pianos (alguns inclusive de semicauda), e muitas se mantinham ocupadas de manhã até à noite. $\mathrm{O}$ custo por ano, para o curso profissionalizante em teatro, somava US\$32.000,00. Segundo dados do Bureau of Labor Statistics do U. S. Department of Labor - espécie de ministério do trabalho dos Estados Unidos — no primeiro semestre de 2016 (período em que realizei a pesquisa) a média salarial por semana de um trabalhador americano era US\$ 823,00. Dessa forma, segundo esse parâmetro, para pagar o curso uma pessoa precisaria trabalhar cerca de 39 semanas ou comprometer aproximada-

2 Com o objetivo de manter interlocutores/as em anonimato, oculto a identificação das instituições e altero os nomes das pessoas. 
mente $75 \%$ do orçamento anual recebido 3 . Durante o primeiro semestre de 2016, observei uma turma formada também por sete pessoas, seis mulheres entre 17 e 25 anos e um rapaz da mesma faixa etária.

Além de acompanhar semanalmente as disciplinas, formulei um roteiro de entrevistas para conversas individuais gravadas com estudantes e docentes. As perguntas tratavam da trajetória de cada pessoa e de suas considerações a respeito do aprendizado, do cenário teatral e da especificidade do teatro musical. No Brasil, entrevistei cinco estudantes e quatro docentes durante o semestre letivo. Já nos Estados Unidos, enfrentei algumas dificuldades. Em minha primeira reunião para explicar o trabalho e pedir autorização para frequentar a escola, fui recebido pelo diretor do programa de Teatro Musical. Curioso (ou suspeito), ele me esquadrinhou com perguntas a respeito da pesquisa: parecia querer avaliar a seriedade do trabalho, bem como a minha competência. Saí da sala autorizado a assistir às aulas, mas com a ressalva de que não poderia realizar entrevistas com qualquer estudante. Segundo ele, muitas/os ainda não haviam completado 18 anos, por isso não poderiam responder apropriadamente em termos legais. Especificamente na turma em que acompanhei as aulas, boa parte do corpo discente estava acima dos 20 anos, mesmo assim optei por não contrariar as orientações e colocar em risco o acesso às disciplinas. Apesar dessas restrições, pude frequentar todas as aulas do semestre e conversar informalmente com docentes e discentes nos intervalos e corredores. $\mathrm{O}$ material apresentado neste texto mescla, portanto, observações feitas durante o campo com as entrevistas realizadas individualmente com algumas das pessoas.

Em etnografias em ambientes escolares, empecilhos burocráticos para o desenvolvimento do trabalho costumam ser comuns (Cipiniuk 2014). Particularmente em escolas de teatro, algumas antropólogas se matricularam como estudantes nos cursos que etnografaram como estratégia de acesso (Ribeiro 2008; Araújo 2009; Peres 2013). Esse não foi o meu caso. Decidi exercer exclusivamente a atividade de observação, inclusive com vista a deixar as pessoas com quem dialogava à vontade para pedirem minha retirada em caso de eventuais constrangimentos.

Cipiniuk (2014) destaca como a posição de quem pesquisa os espaços escolares gera leituras por parte de estudantes: caso o(a) pesquisador(a) permaneça em pé, circulando pela sala, estudantes podem lhe atribuir a função de docente - alguém que deve auxiliar nas atividades; caso se mantenha sentado/a, da mesma forma como estudantes, ou se ficar registrando atividades, a leitura sobre seu corpo ganha outro contorno. No caso das aulas de teatro musical nas escolas estudadas, já estava acordado, pela própria convenção cênica, a existência de uma clivagem: estudantes no palco e uma "plateia" a observar. Se em alguns campos a presença da(o) antropóloga(o) incomoda pela sua não participação, no meu caso, nesses ambientes em particular, esse elemento não constituiu um problema. Atrizes e atores, mesmo aspirantes, trabalham em uma profissão em que é constitutivo serem vistas/ os, ouvidas/os e analisadas/os.

A presença do meu caderno de campo durante essas aulas tampouco trouxe grandes questionamentos. Reconheço existirem situações de pesquisa - e, portanto, pessoas — arredias a anotações simultâneas por parte da(o) antropóloga(o). Ciente de que a minha presença com o caderno poderia gerar algum tipo de desconforto, arrisquei-me. Notei como o próprio caderno conferia um ar de se-

3 “Usual weekly earnings of wage and salary workers, second quarter 2018." (U. S. DEPARTMENT OF LABOR 2018: 5). 
riedade para a minha atividade e contribuía para qualificar positivamente a prática de aprendizado do teatro musical, conferindo-lhe um ar de relevância social. Em algumas ocasiões, as pessoas perguntavam, curiosas, o que registrava. Nessas ocasiões, explicava descrever o que ocorria e até mostrava minha escrita. Outros desafios, contudo, se materializaram. Há um processo de aprendizagem vivido pelo antropólogo enquanto desenvolve sua pesquisa, de modo que no cotidiano do campo perguntava-me: o que devo anotar? Como descrever gestos e entonações? Dedico atenção ao que é falado? Ou me volto aos olhares? Seguramente, falhei em reparar centenas de nuances e, posteriormente, em registrá-las. Por vezes, optei por capturar apenas o que diziam. Notei o quanto perdia. Em outras ocasiões, dediquei-me à descrição dos gestos. Silenciei outras tantas palavras. Assim, o resultado desse experimento é, certamente, parcial e repleto de lacunas.

\section{A audição}

A disciplina audição se dedicava a preparar atrizes e atores para o processo de seleção no mercado de trabalho. Para um(a) produtor(a) profissional, esta corresponde a uma das diversas etapas no desenvolvimento de um espetáculo. Costumeiramente, o seu trabalho começa alguns meses antes, quando decide qual peça montará e, para isso, contrata uma equipe criativa: diretor(a), coreógrafa(o), figurinista e assim por diante. Com o texto em mãos e a concepção estética e artística formulada, inicia-se a procura do elenco.

Para atrizes e atores, a etapa das audições é decisiva, visto que está em jogo tanto o seu desempenho técnico como também outros sinais que condicionam o resultado, conforme veremos ao longo do artigo. No dia marcado, os responsáveis pelo espetáculo - diretor(a), produtor(a), diretor(a) de casting , $^{4}$ diretor(a) musical, coreógrafa(o) - ocupam uma mesa e um(a) pianista fica a postos. A/o candidata/o entra individualmente no ambiente e entrega a partitura da canção previamente escolhida para a/o pianista. A/o artista posiciona-se no centro da sala — diante da equipe técnica e artística —, diz o seu nome, o título da música que vai executar e o nome do musical ao qual pertence a canção. Em seguida, canta poucas estrofes, agradece e sai. A duração não ultrapassa, em média, 2 minutos. Eventualmente, a equipe artística solicita uma informação ou pede para que a atriz ou o ator cante uma nova música. Nesse ínterim, o currículo, enviado para a produção previamente, circula nas mãos dos avaliadores.

Finalizada a primeira bateria de testes, a banca seleciona algumas(ns) candidatas(os). Elas/eles farão o chamado call back, isto é, o retorno para uma segunda etapa. Dessa vez, poderão ler um trecho específico da dramaturgia, cantar uma nova música e, a depender da peça, ensaiar passos de uma coreografia em particular. O número de etapas não é fixo e pode variar, dependendo do grau de competitividade ou de complexidade de cada espetáculo. Conforme explicaria o professor de audição em São Paulo: "A primeira audição é para ver onde você vai encaixar. [...] você não está sendo avaliado, está sendo encaixado. Aí na segunda parte eu quero ver se a pessoa faz a personagem, se alcança a nota”. Por isso, completou o ministrante, "quando te ligam na primeira vez, não significa que você passou para

$4 \mathrm{O} / \mathrm{a}$ profissional responsável em selecionar talentos para uma audição. Quando intérpretes são selecionadas/os, deve lidar com os contratos e o bem-estar das/os artistas. 
outra fase porque você é bom”. Afinal, para passar na etapa inicial da seleção, era essencial corresponder à expectativa física da personagem.

Tanto na escola paulistana quanto na nova-iorquina, estudantes aprendiam uma série de saberes que lhes capacitavam à vida profissional: formatar o seu curriculo vitae, adequar o padrão de fotos para o book pessoal, selecionar o repertório de canções e anotar qual a sequência de etapas de um teste. Não bastava, por conseguinte, dispor das técnicas artísticas para a cena, era imprescindível que jovens soubessem se comportar e, como diria o professor brasileiro, "se vender". Sem alarde, ensinava-se a urgência em reconhecer os "tipos" que os corpos e as vozes permitiriam ser: quem tem o perfil para protagonista em certos espetáculos e quem não tem. Esse tipo de noção agia como bússola que orientava as condutas: as poses para fotos, a escolha das partituras e as formas de se agir.

\section{Como aprender o perfil?}

Em São Paulo, o responsável pela disciplina era o carioca Lauro. Em 2008, com 21 anos, mudou-se para a capital paulista e, desde então, dedicava-se ao teatro musical. O rapaz acumulava a produção de três espetáculos de pequeno porte e a função de professor desde 2010. Em março de 2015, no começo do semestre, uma das primeiras tarefas que Lauro solicitou consistiu em exigir que cada estudante montasse um "book de canções" adequado ao seu perfil. A seleção das partituras seguiria determinados critérios: respeitar o alcance vocal da(o) intérprete (quais as notas mais graves e as mais agudas atingidas); evidenciar uma variedade de ritmos e estilos musicais; demonstrar erudição (medida pela variedade de espetáculos escolhidos, "não pode ser só Disney”); e, por último, corresponder a personagens coerentes fisicamente ao artista. Lauro explicava: "é bom você saber o que você pode fazer em cada musical, qual personagem [fazer teste]”.

Luana, uma das alunas, assentiu e nada disse na ocasião. Nascida em Fortaleza, em 1987, a jovem formou-se em teatro na Universidade Federal do Ceará; decidiu se mudar para São Paulo com a intenção de se especializar em teatro musical. Para sobreviver na metrópole, ainda que tenha conseguido um emprego em uma agência de eventos, dependia dos pais para fechar o orçamento. Durante a nossa entrevista, meses depois daquela aula, perguntei-lhe qual era o seu perfil; ela respirou fundo e me respondeu: "No começo, eu era bem resistente a essa história do perfil do musical". Após algum tempo, contou como mudou de opinião: "Fiquei convencida de que é mais fácil as pessoas conseguirem entender aquela história ali por conta do perfil. É uma coisa que não precisa de explicação, ela já está vendo. É uma comunicação muito mais direta”.

A atriz apontou para o seu book de canções sobre a mesa: "Eu acho que nas músicas que estão aqui [no book] eu tenho perfil vocal. O perfil físico eu tenho da maioria. [...] Talvez a mais distante seja a Ariel [do musical $A$ Pequena Sereia] ". Intrigado com a limitação, eu a estimulei a falar mais. "Não sei. Acho que justamente por ser uma princesa da Disney as pessoas têm muito na cabeça o que seria

5 Musical produzido pela Walt Disney, estreou na Broadway em 2008. O espetáculo é baseado no filme de 1989 de mesmo nome. Na história, Ariel é uma sereia que se apaixona por um homem, o príncipe Eric; por ele, a jovem realiza sacrifícios, como entregar a sua voz para a Bruxa Úrsula em troca de transformar a sua cauda de peixe em pernas humanas. 
uma Ariel". Conforme completou: "Dificilmente um diretor me veria como Ariel [...]. Não sei se ele me veria em algum momento como alguma princesa”. Perguntei-lhe o motivo pelo qual não poderia "ser uma princesa". Respondeu não saber e sentenciou: "Eu acho que eu não tenho perfil de princesa. [risos]. Para o que a vida inteira, eu comprei como princesa [risos]". Cada vez mais reflexiva, expôs uma aspiração antiga, o sonho de fazer a protagonista do musical A Bela e a Fera: "Eu amaria, né? Eu fico triste em dizer isso. Mas eu acho que um diretor, ainda que artisticamente falando eu trouxesse para ele todos os aspectos, psicológicos, da personagem, eu não sei se ele me compraria como Bela. Por perfil físico mesmo".

Insisti para que Luana explicitasse os significados daquela queixa. Afinal, o que seria o "perfil Bela"? "Acho que teria que aparentar uma aparência mais menininha. [...]. Um cabelo mais liso. Mas poderia ter peruca. Mas assim, a olho vivo, sem nada, talvez ele me visse mais como mulher do que como menina”. Avançando na sua análise, a jovem expôs: "Acho que o fato de eu ter o cabelo enrolado, cabelo grande, volumoso, ter os seios grandes, ter o rosto mais redondo, não ter o rosto afilado, isso já traz muita informação sem eu abrir a boca". Rindo com a voz levemente embargada, a fala final encerraria o assunto: "Confesso que essa é uma frustração, porque como atriz eu poderia fazer a Bela”.

A respeito dessa longa passagem, chama a atenção como para discutir práticas de aprendizagem é necessário considerar as dimensões político-econômicas, as disputas históricas e os repertórios sociais envolvidos (Lave 2015). Em ambientes de ensino, algumas categorias despontam como suporte para comunicar informações e valores, como o caso do bullying analisada por Bazzo (2017b). A noção perfil, nesse sentido, sintetizava referenciais sociais, valores historicamente constituídos e um procedimento pedagógico singular.

Em primeiro lugar, a categoria definia o corpo de estudantes (mas também de artistas) como uma plataforma de significados. Carregado de história, cada sinal diacrítico impunha a sua presença sob os holofotes: tonalidades de pele, tipos de cabelo, textura dos fios, silhueta, idade, voz e afins adquiriam contornos em relação. Os cabelos enrolados, volumosos, e o rosto arredondado demarcavam uma fronteira entre Luana e Bela. Por comparação, a personagem precisaria ter rosto afinado e cabelos lisos. Ao salientar os seios grandes, a estudante destacava que em Bela essa característica deveria estar ausente. $\mathrm{O}$ imaginário exigia a seleção de uma menina branca e com poucas curvas. A fala justificava a relevância do perfil: o seu corpo já imprimia muitas informações sem que ela "abrisse a boca”. A materialidade ofereceria acesso ao conteúdo do espetáculo, isto é, traria consigo significados - uma história, um imaginário - que, em cena, se atualizavam e, naquele exemplo, seriam incompatíveis.

Em segundo lugar, o termo perfil acionava repertórios estéticos antigos e alheios ao ambiente educacional, afinal, o ato de derivar o comportamento de personagens femininas a partir do formato físico de atrizes não é novo. Hirano (2015) frisa como, entre os anos 1940 e 1950, as atrizes brancas de cinema exibiam uma pele inegavelmente clara, um corpo esguio e um rosto afilado, ao passo que as intérpretes negras, presentes nas telas, possuíam outro tipo físico: as formas arredondadas estavam fora dos parâmetros de beleza e de sedução construídos por Hollywood. As convenções estéticas do período constituíram-se sob os repertórios de beleza racializados e produziam critérios de seleção excludentes. 
Especificamente no caso de Luana, os parâmetros estéticos emanavam de um imaginário das princesas Disney — igualmente presente em outros ambientes educacionais. Em escolas no interior de São Paulo, por exemplo, as crianças interlocutoras de Escoura (2012) asseguraram-lhe que o manejo adequado de bens (coroa, joias e vestidos caros), da aparência (uma beleza entendida como "branca" e jovem), do comportamento (associado à delicadeza de gestos e vozes) e do relacionamento (a expectativa de uma relação monogâmica heterossexual e romântica com um príncipe) constituíam os critérios fundamentais para classificar uma princesa. No que toca a Luana, a aparência soava como o maior problema para que ela interpretasse Ariel ou Bela. Para além dos cabelos e do formato de rosto, ela declarava ser "mulher" e não "menininha”. Em razão dos 29 anos completos, a atriz não corresponderia ao imperativo juvenil da personagem. Entretanto, a polaridade "mulher" e "menina" não parecia se restringir a um quesito etário.

Durante a entrevista, quando ela discorreu a respeito de sua "cor/raça", destacou sua história: "eu me vejo com características de muitas coisas. Assim, da minha família, a minha mãe ela é neta de índios - índios mesmo - com holandeses, e meu pai, de portugueses com negros”. Em seguida, concluiu: "Então eu tenho um cabelo mais voltado para o afro - enrolado - uma boca mais carnuda e tal. Mas ao mesmo tempo, na cor da pele eu sou branca. Assim, né? Eu sou mais clara”. Por fim, sentenciou: "eu sou misturada". Seus atributos físicos, quando comparados ao "imaginário Bela" (jovem, sem curvas, "inocente" e branca), poderiam ser percebidos de tal maneira que acionariam repostas eróticas, dada a própria forma como mulheres "misturadas" - para usar os termos da jovem — foram constituídas no imaginário nacional (Gonzales 1983; Corrêa 2007; Moutinho 2004). Noções como "mistura" e "miscigenação" costumam ser mobilizadas para produzir, de maneira perversa, a sensualidade de mulheres não brancas.

Luana aprendia, via a categoria perfil, como a erotização feita sobre seu corpo a afastaria do temperamento esperado de uma "princesa". A própria posição social de seus ancestrais seria incompatível com a trajetória de uma suposta nobreza. Adriana Piscitelli $(2008,2011)$ sinaliza como em países da América Latina e do Caribe - com histórias marcadas por relações coloniais e regimes escravocratas — houve um processo de sexualização racializada da subalternidade e da pobreza, constituindo-se um tropo imagético que impediria associar uma pessoa como Luana a uma personagem da realeza Disney.

Por fim, em terceiro lugar, do ponto de vista da forma de aprendizado, a estudante não identificou um único professor ou uma disciplina em particular como responsáveis em listar quais as personagens ela poderia possivelmente interpretar. As considerações sugerem como a convenção exigia a autopercepção e a autoclassificação da própria atriz. Estudantes deveriam aprender, tácita e silenciosamente, como incorporar tais regras. O debate sobre relações étnico-raciais no Brasil estava ausente naquela escola e experiências como vividas por Luana não ganhavam estatuto de assunto a ser nomeado e discutido como prática violenta (Gomes 2005; Ratts 2016).

Em Nova York, o procedimento de aprendizado da convenção guardava aproximações com o caso brasileiro. O responsável pela disciplina era o professor Brad - formado em Theater Studies em uma universidade prestigiosa da Costa Leste norte-americana. Nos primeiros anos da sua carreira, ele 
dirigiu produções teatrais em diversas cidades do país, posteriormente dedicou-se à composição, acumulando, até 2016 (ano da minha pesquisa), dez diferentes montagens.

Em uma manhã, a atividade consistia na simulação de uma entrevista de emprego. Brad interpretaria um agente em busca de novos talentos. Sentado atrás de uma mesa, o ministrante ordenou para que todas(os) estudantes aguardassem do lado de fora. Uma a uma, a pessoa entraria, responderia uma curta entrevista e sairia. A intenção era preparar as(os) futuras(os) profissionais para a lida com empresários e agentes. Abaixo reproduzo duas dessas encenações com estudantes distintas:

1. Brad - Eu sou um agente de casting e quero conhecer você.

Sandra - Eu sou do México e faço Teatro Musical desde os 13 anos. Ano passado em vim à escola para visitar e amei.

Brad - Onde você se vê na indústria do entretenimento?

Sandra - Em um show?

Brad - Não. Na indústria do entretenimento.

Sandra - Eu poderia estar no Alladin, no Fiddler on the Roof. Mas também no In the Heights ${ }^{6}$. Eu adoraria ser a Elphaba no futuro [protagonista do espetáculo Wicked]. E também trabalhar em um cruzeiro.

Brad - Qual o seu personagem dos sonhos?

Sandra - Viajar e fazer tour shows ${ }^{7}$.

2. Brad - Olá, eu sou Brad. Sou um agente. Como você veio parar na escola?

Andressa - Eu morava na Inglaterra; vi que tinha o programa de Teatro Musical e decidi vir para cá.

Brad - Onde você se vê?

Andressa - Eu me vejo fazendo Shakespeare. Me vejo em personagens mais novos. Ou como a amiga da protagonista.

Brad - Qual o seu personagem dos sonhos?

Andressa - Lucinda e Cinderela no Into the Woods.

Brad - Você se vê como a meia-irmã? [Lucinda é a meia-irmã de Cinderela no espetáculo]

Andressa - Eu sempre sou o alívio cômico.

Depois dessas duas entrevistas, enquanto aguardávamos a próxima pessoa entrar, o professor voltou-se para mim e disse: "Viu como essa última foi bem? Ela sabia o nome de vários personagens: ela sabe o que quer, tem personalidade; ao contrário daquela outra que queria fazer tour show. Eu nem sei o que é isso! E isso faz ela parecer burra”. Ali, o professor compartilhava suas impressões comigo como se desejasse me ensinar como olhar a situação. Finalizada a bateria de audições, Brad arrolou considerações gerais para a turma e fez questão de parabenizar Andressa: "Você mostrou que sabe das coisas quando falou o nome das personagens em musicais específicos”. Em tom irônico, endereçado

6 A jovem listou uma série de espetáculos nos quais o elenco é formado, majoritariamente, por "people of color" [pessoas de cor], para utilizar o termo êmico. Alladin passa-se na Índia, Fiddler on the Roofé protagonizado por judeus e In The Heights aborda um bairro latino em Nova York.

7 Refere-se a espetáculos apresentados em um circuito, em diversas cidades. 
àquelas(es) que não foram precisas(os) nas respostas, emendou: "Imagina um diretor de um hospital perguntando para um médico o que ele usaria em uma cirurgia e ele responder "sei lá, eu quero usar o negócio de laser para fazer aquela coisa na cirurgia'”. Os risos rebateram, desconfortáveis, pela sala.

Durante as aulas, o procedimento de ensino adotado recorreu a duas estratégias: a simulação de situações profissionais e o incentivo via elogio. A respeito da primeira, o jogo de papéis reforçava o objetivo da escola, isto é, ensinar estudantes na carreira de atrizes e atores. O exercício criava uma metalinguagem na qual estudantes (de teatro) encenavam a si mesmas(os) em uma entrevista de emprego fictícia. Sobre a segunda estratégia, Brad recompensava quem já dispunha de códigos para saber se alocar no mercado. Andressa, segundo os critérios do docente, se posicionou de forma precisa: o seu sotaque inglês, em plena Nova York, poderia qualificá-la para interpretar Shakespeare e, ao mesmo tempo, soava perspicaz, ao se identificar como "amiga da protagonista" "meia-irmã" ou "alívio cômico". Ao que tudo indica, o seu corpo não estaria apto para interpretar uma protagonista, o que se verificou pela concordância entre o professor e a estudante, sugerindo que a norma já estava devidamente subjetivada e operante.

Portanto, apesar do conteúdo ensinado - "as técnicas da audição" — ser relevante, a forma de ensino da noção do perfil era fundamental. Nas aulas em São Paulo e Nova York, aprendiam-se tacitamente e implicitamente os limites e as possibilidades fenotípicas de corpos em um mercado concorrido. Inclusive, outorgava-se a tarefa classificatória para as(os) próprias(os) estudantes. Dessa forma, professores tangenciavam o problema e evitavam o risco de serem acusados de racistas, machistas, LGBTfóbicos, gordofóbicos ou afins. Se em escolas de ensino formal, algumas diferenças físicas ou comportamentais tornavam-se alvo de bullying ou meio para agressões (Bazzo 2017a; Miranda, Maia 2017), no ambiente dessas escolas de teatro musical, cada pessoa realizava o próprio diagnóstico tipológico, de modo que a responsabilidade pela classificação era individual. Havia, inclusive, uma valorização de quem fosse "mais autoconsciente": o controle e a apresentação do corpo tornavam-se responsabilidade $\mathrm{da}(\mathrm{o})$ própria(o) artista.

Apesar do termo perfil ser enunciado continuamente, não presenciei nenhum momento em que qualquer professor anunciou: "este é o seu perfil”. O método de sugestões, indicações e broncas implícitas evitava chamar a atenção para a dimensão estrutural que sustentava o processo racializado, generificado e sexualizado, que limitava sujeitos. Aos poucos, havia uma sedimentação e uma naturalização dessa categoria nos corpos e experiências de estudantes.

\section{As normas a serem aprendidas}

Enquanto a maioria das estudantes trocava de roupa e se preparava para o início das atividades, uma das jovens se aproximou. Fazia calor em São Paulo, eu acabara de chegar e ainda me acomodava na sala. Sentei em uma cadeira próxima à porta e abri a mochila em busca do meu caderno de campo. Ela me cumprimentou e emendou a pergunta: "Você tem vontade de fazer aulas e ver como se sai?". Levemente surpreso e um tanto intrigado, sorri. Expliquei a ela que o meu interesse era apenas na pesquisa 
e quis saber o motivo da pergunta. Em tom de incentivo elogioso, ela justificou: "talvez você tenha o perfil". Satisfeita, logo se afastou, caminhando em direção às colegas.

Em algumas pesquisas antropológicas, pesquisadoras lograram acesso à sala de aula por contribuírem com as práticas pedagógicas, como a condição de "professorinha" de Cipinuk (2014) e de "tia" de Escoura (2012). No meu caso, o trânsito nessas instituições educacionais pode ter sido influenciado, entre outras coisas, por minha aparência. A condição de homem branco, de olhos claros e cabelos loiros parecia sintonizar com os atributos de um potencial estudante. Apesar de ligeiramente mais velho na época contava com 29 anos - , a idade não parecia ser um fator excludente, afinal, eu teria o "perfil". A categoria fazia parte não apenas do sistema classificatório de corpos, mas também indicava as regras para o sistema de pertencimento daquele ambiente pedagógico.

Instantes depois, a aula começou. Naquele mês de abril de 2015, o professor Lauro passou a realizar regularmente a simulação de audições — de forma próxima ao exercício adotado por Brad. Ele se sentava atrás de uma mesa e pedia para as estudantes se apresentarem enquanto avaliava a interpretação das jovens. Cada uma entrava sozinha na sala, dizia o nome, entregava o currículo, anunciava o musical para o qual faria a audição e a personagem ambicionada, cantava uma música da sua escolha, agradecia e, por fim, saía. A proposta da aula era "ensaiar" para esta etapa importante. Em diversas ocasiões ele interrompia as jovens por considerar suas escolhas equivocadas e ordenava: "quero ouvir algo mais dramático" ou "você precisa apresentar uma música próxima ao que pode interpretar".

Em uma ocasião, o professor ficou particularmente aborrecido com o que considerou um "desleixo" estético das meninas: "O corpo é nosso cartão de visitas!"; repreendeu: "Precisam vir arrumadas. Não pode vir de meia. Tem que vir de maquiagem!”. Apontando para uma das estudantes, a sua fúria cresceu: "Ela está de meia, de moletom". O sermão deslocou-se para as diretrizes: "É blush, cabelo arrumado; é diva! Isso é muito importante, a gente não sabe quem vai encontrar”. O emprego reiterado do verbo "ser" com o tom imperativo - "é blush", "é diva" - indica uma vigilância às práticas. Se professores não definiam o "perfil" específico de discentes, eles fiscalizavam as suas escolhas estéticas e comportamentais.

Em seguida, o docente emendou: "O bom senso é primordial". Segundo ele, alguns parâmetros, não explicitados, deveriam definir o uso dos recursos cosméticos. Lauro contou, então, uma anedota sobre a ocasião em que compôs a banca de seleção para um musical e uma atriz apareceu com um batom rosa nos lábios, “bem 'piriguete”." "Logo após as primeiras estrofes da canção, o diretor musical pediu para ela cantar uma música de outra personagem. E cantou lindo, mas eu só via ela para a personagem 'piriguete' por causa do batom rosa'. O pigmento labial teria sido o responsável pela reprovação da candidata. Encerrado o sermão, as estudantes ficaram em silêncio. Dispensadas, elas recolheram os seus pertences e saíram.

Setes dias se passaram e, antes mesmo de a aula começar, os rostos das aspirantes a atrizes terminavam de ser maquiados: blush, batom, rímel, lápis... Uma delas apareceu com bobs nas madeixas loiras recém-pintadas, explicou que queria "segurar até a aula”. Enquanto fazia os últimos ajustes nos cílios, anunciou às colegas: "Vou mijar!”. Deu uma risada e ironizou: “A lady!". A colega emitiu um comen- 
tário bem-humorado: "Essa sala só tem ogra". Endereçando-se para mim, remediou ironicamente: "Só tem Barbie aqui. Só tem princesa!".

Minutos depois, Lauro entrou na sala e sorriu: "Então vocês estão aqui, lindas, cheirosas...”. Acrescentou, em seguida, uma nova orientação. A preocupação não poderia se restringir ao cabelo e à maquiagem, "A aparência é o todo. É como você quer se vender para a audição". Retomando a possibilidade elástica da seleção, sugeriu: "Se você precisa do trabalho e quer vender mais velho, então faz algo". Mas rapidamente ratificou: "Aí a pessoa tem um perfil virginal e passa um quilo de maquiagem e fica com cara de puta suja". Ora a tonalidade dos cosméticos (a cor rosa do batom), ora a gradação da maquiagem ("um quilo") poderia comprometer a apreciação do trabalho das jovens. A feminilidade assumida como moralmente condenável ("piriguete" ou "puta suja") danificaria a imagem de uma intérprete por confundi-la com outro tipo de profissional.

Diversas pesquisas em ambientes educacionais indicam como o vocabulário de gênero atravessa as relações desenvolvidas entre discentes e docentes (Carvalho 2004; Escoura 2012; Miranda e Maia 2017). Particularmente em escolas de teatro, a associação entre atrizes e prostituição ronda as salas de aula (Coelho 1989; Araújo 2009). No caso observado, as avaliações professadas escoravam-se em referências alinhadas a expressões de feminilidade bastante restritivas e regulatórias.

Termos como "piriguete" e "puta suja” contrastavam com as próprias classificações irônicas acionadas pelas jovens: "Barbie" e "princesa”. Estas últimas eram evidentemente vinculadas à ideais de beleza, posse, brancura e a uma feminilidade elegante (Escoura 2012). Entre a classificação "perigosa” e a “ideal", estudantes pareciam preferir se remeter a uma outra via: a "ogra”, cujo significado seria amplo o suficiente para permitir uma mulher ser "linda e cheirosa" e, simultaneamente, falar alto e empregar um vocabulário em nada sintonizado com o esperado das "princesas" ("mijar”). As discentes aludiam, quiçá, à personagem Fiona, do filme Shrek $(2001)^{8}$. No enredo, a protagonista é uma jovem princesa que foi amaldiçoada quando pequena. Transformada em uma ogra, seria liberta do feitiço quando beijada por um príncipe. As atitudes da personagem no longa-metragem oscilavam entre um comportamento cortês e outro mais debochado - como quando participa de uma "competição" de arrotos. Talvez por isso as jovens brincassem com essa referência e, dessa forma, reagissem aos qualificativos pejorativos e estreitos definidos por docentes.

As normas da instrução paulistana assemelhavam-se àquelas preconizadas em Nova York. Em uma manhã de maio de 2016, em Manhattan, quando se discutia como as jovens deveriam se vestir, uma delas sugeriu: “Como em uma entrevista de emprego?”. Categórico, Brad postulou: “Não. Eu quero que vocês cheguem gostosas [Hot]". O professor compartilhou as suas experiências como membro de bancas de seleção: "O que eles [produtores, diretores] falam atrás da mesa [a respeito das candidatas]?”. Depois de um breve instante de silêncio, respondeu a própria pergunta retórica: “Você comeria ela?’”. Em seguida, tentou escusar-se: “É horrível. Eu escutava: 'Ela [uma candidata não explicitada por ele] é tão boa, mas é a última pessoa do mundo que eu comeria’. E ela não conseguiu o papel”. A conclusão foi ostentada como sugestão: "Você quer muito ser a gostosa".

8 Filme animado da DreamWorks baseado no livro Shrek! Em 2008, a história foi levada aos palcos da Broadway, permanecendo em cartaz por dois anos. 
Mas mesmo a erotização, ressalvou Brad, precisaria ter limites: "em nenhuma circunstância faça pornô”. O mercado pornográfico constrangeria produtores na seleção de artistas. Um ator profícuo, segundo seu relato, deixou de ser contratado pois "vazaram" imagens "gays" dele: "Se alguém for dar um Google, aparecem as fotos e todo mundo tem medo disso". Por isso, "você tem que tomar cuidado com quem você sai e namora. Você é um produto e alguém pode querer te destruir”. Timothy, o único rapaz da turma, quis saber quais seriam as prescrições específicas para os homens. O conselho foi certeiro: não use roupas muito apertadas, "eles não querem saber a sua religião, se vocês sabem o que estou dizendo.... A frase do professor soou ambígua. Por um lado, aludiria diretamente à circuncisão da fimose peniana tradicionalmente realizada em homens praticantes do judaísmo. Por outro, uma calça justa poderia ser indício de outra "igreja”, a homossexualidade. Nesse caso, ser gay — ou apresentar-se com outras masculinidades - criaria o risco de cercear o horizonte de trabalho e interditar o avanço da carreira.

Em outro trabalho, já refleti sobre formas pelas quais aspirantes a atores negociavam expressões de masculinidade no processo para interpretar personagens (Machado 2019). A respeito do jogo de visibilidade e invisibilidade entre os bastidores e o palco, retomo brevemente uma das entrevistas que realizei com Simon, um rapaz de 21 anos, cisgênero, alto, branco, loiro, musculoso e jogador do time de lacrosse da universidade. Na peça da faculdade, ele interpretava o personagem principal, um operário do show business americano do início do século XX que ganhava a vida com entretenimento e era o par amoroso da protagonista. Durante a nossa entrevista, perguntei-lhe a respeito de como via as diferenças entre ele e a sua personagem. A princípio, Simon não entendeu. Expliquei: "Por exemplo, vocês têm a mesma idade? A mesma classe social? A mesma orientação sexual?”. "Ah! Bem, ele é mais velho do que eu, de uma classe mais baixa, eu diria. Sobre a orientação sexual eu prefiro não falar". Depois da recusa, seguimos a conversa. Instantes depois ele se manifestou: “Por que eu fiz isso? Sim, eu sou gay!".

De acordo com Eve Sedwick (2007), cada novo encontro exige, pelo menos da parte de pessoas gays, novos cálculos de sigilo ou exposição. Esse rapaz, durante a entrevista, avaliou, entre a primeira e a segunda resposta, se poderia/deveria "revelar" a sua sexualidade. A própria metáfora do "armário" comum na comunidade LGBT — alude ao par segredo/revelação que também opera nos palcos: o que um ator esconde e o que revela? Simon parecia temer que um elemento (um gesto, uma roupa, um tom de voz) funcionasse como gatilho para uma série de inferências que revelariam a sua "realidade sexual".

A fiscalização convergia com as normativas ensinadas na escola de teatro musical nova-iorquina. Timothy ainda perguntaria ao professor: "qual tipo [de ator] se procura mais?”. Sem piscar, Brad respondeu: "O mais difícil é o homem protagonista. O Hugh Jackman". O que dança e canta. Isso é raro". O parâmetro era um artista "viril", alto, forte, explicitamente heterossexual e branco. Esse "perfil" asseguraria emprego e estabilidade no mercado, talvez por isso Simon tivesse titubeado durante a nossa conversa.

Conforme se aprendia nos estabelecimentos de ensino das duas metrópoles, as seleções exigiam "profissionalismo". Brad diria: "Não basta ser o melhor cantor e dançarino do mundo. Se você não for profissional, isso me faz questionar você. E você não estará se vendendo". Lauro concordaria: "É

9 Ator, cantor e produtor, nasceu em 1968, em Sidney. Desde a década de 1990 trabalhou em produções de teatro musical e no cinema na Austrália, Inglaterra e nos Estados Unidos. Em boa parte de sua carreira, ele deu corpo aos homens protagonistas. 
entrevista de emprego". Pacificada a percepção de que eram, de fato, mercadorias, estudantes aprendiam como apresentar os seus corpos e comportamentos e atendiam a condutas bastante restritivas: fiscalizavam as apresentações de gênero (feminilidade e masculinidade) e o próprio cuidado estético. Regulava-se, inclusive, o que as apresentações poderiam sugerir em termos de práticas da sexualidade. Tais normas se manifestavam de modo violento nos ambientes de aprendizado. Nos cálculos de como se expor, cada intérprete deveria ajustar sua fisicalidade — e, nesse caso, o seu "perfil" — às expectativas específicas do que chamavam de "mercado".

O processo de aprendizado, portanto, se instaurava com regras e etiquetas que, se descumpridas, poderiam comprometer a carreira profissional de artistas. Estudos evidenciam como o comportamento dos corpos - atravessados por referenciais de gênero e de raça — informam processos pedagógicos e avaliações (Silva et al. 1999; Carvalho 2004). No caso do teatro musical, naquelas escolas não era diferente: tratava-se de um aprendizado repleto de restrições e estímulos. Se em algumas escolas docentes se negam a discutir a sexualidade de discentes ou a tratar explicitamente das normativas de gênero (Junqueira 2010), nas duas escolas de teatro musical observadas, docentes explicitamente afirmavam que apenas algumas posturas específicas poderiam garantir sucesso em uma profissão tão competitiva.

\section{Cumplicidades, burlas e restrições}

Com duas semanas de antecedência, o professor Lauro solicitara a entrega de um currículo vitae de cada estudante de modo a avaliar como a classe se apresentava. Naquela noite, os documentos foram trazidos com anotações. O ministrante começou listando as informações que as jovens haviam inserido: nome artístico; qualificações (se é atriz, cantora, dançarina) e nome completo; endereço, e-mail e telefone; $\mathrm{DRT}^{10}$; data de nascimento e naturalidade; idiomas; especificações físicas (altura, peso, sapato) e foto de corpo inteiro. Erguendo os olhos do papel, encarou cada uma delas. O professor perguntou: "Para quê serve um currículo?". Luana adiantou-se: "Para quando você for selecionada"; recebeu um "não" como resposta. Ela insistiu: "Para mostrar quem é você e o que você já fez de uma forma objetiva?". Dessa vez, a resposta foi positiva. O documento arrolaria as informações pessoais, a trajetória profissional, a formação educacional, os cursos realizados e as habilidades extraordinárias, entregando a produtores(as) uma versão bastante particular da trajetória de artistas.

Capitaneando a aula, Lauro orientava: "Vamos colocar data de nascimento no currículo?”; Luana respondeu: "Já sabemos que não; denuncia a idade". Outra aluna completou: "E a idade limita". Em seguida, ele continuou: "Devemos colocar 'naturalidade'?". Por "naturalidade" compreendia-se a região onde nasceram - cidade e estado —, a origem familiar e/ou a ascendência étnico-racial. Uma das meninas, até então quieta, arriscou "Pode ser útil", mas logo foi interpelada por Luana, que afirmou: "A pessoa pode aparentar várias coisas. E nada que limita é bom”. Entendendo-se como "misturada”, conforme discutido em seção anterior, Luana apostava em uma interpretação elástica a respeito do seu

10 A sigla corresponde à Delegacia Regional do Trabalho e se refere a um atestado de capacitação profissional, um selo (ou carimbo) afixado na carteira de trabalho que confirma a competência profissional de uma pessoa para determinada área. Existem diversos tipos de DRT: para radialistas, locutores(as), diretores(as), modelos, cantores(as), bailarinos(as), atores/atrizes, entre outros. 
corpo. Temia privar outras potenciais leituras, caso inserisse alguma informação demasiadamente específica. Os dados pessoais fornecidos eram, portanto, significativamente moderados: nome artístico, registro profissional (DRT), e-mail e telefone.

Apesar da importância de cada artista constatar “ter ou não ter o perfil”, era facultada a omissão estratégica, conforme sugeriu Lauro. Tal característica residia na singularidade brasileira diante das regras "americanas". Segundo o docente, os "gringos" estranhavam quando vinham ao Brasil para um trabalho: "Eles chegam com expectativas [...]. E o perfil [que exigem] é muito específico". Particularmente alguns produtores nutriam a fama de serem muitos rigorosos: "Eles dizem que precisam de uma pessoa que canta, dança e tenha $1,58 \mathrm{~m}$ ”. No caso nacional, o professor aconselhava: "deixem a banca decidir por vocês". Tomando a sua experiência como exemplo, Lauro contou como em um determinado espetáculo decidiu não mandar o currículo, avaliando que somente seriam selecionados "caras bombados e altos". Amargou ver que só passaram no teste atores baixos e não tão "definidos".

Assim, apesar das fiscalizações, Lauro apostava na possibilidade da burla, isto é, nas chances de artistas poderem escapar - ainda que de forma muito limitada — das restrições feitas a seus corpos (Pontes 2010). Sob a expectativa de interpretar uma gama diversificada de personagens, professor e jovens não revelariam (ao menos no currículo) a idade, a cor/raça, o local de nascimento, a altura, o peso e outras características físicas particulares. A classificação em termos geracionais e raciais dependeria não de quem elaborasse o currículo, mas sim de quem avaliaria os corpos. Com algum grau de maleabilidade, artistas poderiam se trajar e se maquiar para aparentar ser mais novas(os) ou velhas(os). O professor até adotou um bordão, repetido em diversas aulas, para orientar as estudantes: "Diga a verdade, mas não a verdade inteira”. Esse tom de aconselhamento costurava os conteúdos ministrados e gerava uma espécie de camaradagem entre docentes e discentes. As falas desprovidas de formalidade e as anedotas de bastidores contribuíam, aos poucos, para a sedimentação das informações apresentadas.

Se no Brasil ensinava-se que uma omissão do perfil, sobretudo no currículo, poderia garantir vantagens, no caso dos Estados Unidos, o preenchimento de um elenco só poderia ser realizado a partir de um tratado, quase exaustivo, das características físicas de intérpretes. Por exemplo, durante o semestre de aulas, o professor Brad também designou a seus alunos a tarefa de elaborar um currículo a ser avaliado em sala. O formato era basicamente o mesmo encontrado em São Paulo. Em destaque, o nome artístico, em seguida, com letras menores e à esquerda da página, o e-mail, o telefone e o site pessoal. Relacionavam-se, então, os trabalhos teatrais em Nova York e em outras cidades, as participações cinematográficas, a formação educacional e as habilidades extraordinárias, tais como as línguas faladas, os esportes praticados, os estilos de dança habilitados, os instrumentos tocados e afins. Destoava do caso brasileiro um conjunto de informações dispostas logo ao lado dos dados pessoais (e-mail e afins): a altura, o peso, a cor dos olhos, a cor do cabelo e o timbre de voz (soprano, contralto, barítono...).

As informações propositadamente omitidas em São Paulo eram as mesmas destacadas nos currículos de Nova York. Não à toa, em sites de busca de atrizes e atores nos EUA, esses dados figuram como descritivos possíveis. O Backstage é uma plataforma de talentos dos Estados Unidos, com mais de 50 anos e agrupa cerca de 100 mil membros de todo o país. Semanalmente, a empresa divulga cerca de 4.000 papéis para audição em novas peças, filmes, programas de TV e campanhas publicitárias. Dentre 
os serviços disponíveis do site, dois são os principais: a promoção de novos projetos de trabalho, assim atores/atrizes, modelos e performers podem submeter os seus currículos e ser selecionadas/os para participar de audições; e a ferramenta de busca, para que produtores(as), diretores(as) de casting e agentes encontrem atores e atrizes, de acordo com o perfil que procuram.

Para selecionar um "talento", o usuário pode combinar diversos filtros: gênero; faixa etária; “etnia” (asiático, negro/afro-americano, ambíguo etnicamente/com múltiplas raças, indígena, latino/ hispânico, nativo do Oriente Médio, sul-asiático/indiano, nativo do sudeste da Ásia/das ilhas do Pacífico, branco/descendente de europeu); tipo físico (mediano, magro, atlético/tonificado, musculoso, curvilíneo, encorpado/atarracado, plus-sized/full-figured ${ }^{11}$ ); cor do cabelo; cor dos olhos e faixa de altura. Essa ferramenta garante, aos olhos dos(as) produtores(as) e diretores(as) estadunidenses, eficiência para encontrar a(o) atriz/ator que atenda ao tipo físico almejado para o novo trabalho. A plataforma, por meio da sua estrutura, realiza uma espécie de "filtro da diferença”. A operação consiste em peneirar digitalmente determinados aspectos fisionômicos.

A respeito dessa prática classificatória, as advertências de Brad flertavam entre a rispidez e a resignação: "Cada ator é dispensável. Se você quer ir comer hambúrguer, não se sinta mal na audição. E se você não gosta disso, esse mundo não é para você. Se você quer defender o direito de homens e mulheres serem como quiserem, ótimo. E isso vai ser viável no teatro? Duvido". Empenhado em suavizar seu argumento, justificou: "Isso me faz feliz? Não. [...] mas você não pode mudar algumas coisas". A conformada conclusão procurava pôr panos quentes no debate, relegar a responsabilidade para um "sistema" inalterável e transformar estudantes e Brad em vítimas dessa mesma indústria de entretenimento. O procedimento retórico de compartilhar suas sensações alocava-o numa posição próxima daquela vivida por estudantes, afinal, ele também era um artista.

Sobre essas passagens interessa destacar dois aspectos. Em primeiro lugar, salientar como o sistema classificatório adotado pelas escolas (ao menos no que tange ao recrutamento de artistas para teatro musical) guardava algumas diferenças. Em São Paulo, cobrava-se a ciência do perfil, mas, simultaneamente, outorgava-se à produção avaliá-lo. Lauro ensinava a omissão e previa ser possível silenciar ou negociar aspectos físicos de intérpretes. Em Nova York, Brad insistia na exaustão descritiva e promovia um enquadramento definido e supostamente preciso para cada pessoa. Assim, em São Paulo havia uma ligeira margem de negociação e, em Nova York, uma descrição detalhada. Nota-se como o perfil era ora enfatizado, ora silenciado e ainda negociado, a depender dos contextos.

Em segundo lugar, apesar dessas diferenças classificatórias em cada escola, os dois professores adotavam, no processo de ensino, um tom de aconselhamento. Eles enunciavam o conteúdo como se estivessem revelando os bastidores de um universo pouco acessível para quem não era iniciado. $\mathrm{O}$ vocabulário informal, os casos citados, os bordões e o compartilhamento de suas sensações pessoais contribuíam para estabelecer uma relação de cumplicidade entre docentes e discentes, além de desarmar, pela suposta proximidade, as eventuais desconfianças. Por sinal, não é descartável o fato de que ambos os professores eram também artistas e trabalhavam no setor - como atores, diretores e produtores. Esse tipo de posição garantia uma comunicação que era, a um só tempo, vertical — de docentes para dis- 
centes e de uma geração mais velha para outra mais nova - e horizontal - entre colegas de profissão. Este último aspecto parecia transformar os enunciados violentos e restritivos característicos do perfil em conselhos de carreira. Forma e conteúdo das aulas mantinham-se, dessa maneira, indissociáveis.

\section{O perfil e a personalidade}

As normas relacionadas aos diferentes perfis orientam não apenas estudantes, mas transbordam para profissionais consagrados no ramo do teatro musical. Em 2005, por exemplo, o experiente intérprete Saulo Vasconcelos ${ }^{12}$ expunha a relevância da convenção para o jornal Folha de S. Paulo (2005: E3). $\mathrm{Na}$ véspera da estreia do musical O Fantasma da Ópera, a reportagem perguntou-lhe como encarava ser reiteradamente recrutado para interpretar vilões, ao que respondeu: "O ator tem uma certa forma, uma carreira traçada, um tipo físico. Não adianta ser como eu, de $1,88 \mathrm{~m}$, querer fazer o papel do franzininho, romantiquinho, galanzinho. Tenho o estereótipo do vilão, mas obviamente cabe aos produtores e diretores verem que possuo versatilidade para fazer outras coisas". Apesar da sua disposição, até 2015, dentre os nove grandes espetáculos em que trabalhou, em seis deles fez personagens cujas ações e comportamentos poderiam ser enquadrados como vilóes. Outro ator bastante ativo no mercado nacional, Jarbas Homem de Melo ${ }^{13}$ reforçou a relação entre a função da personagem e o timbre da(o) atriz/ator: "a boazinha é sempre soprano, a mazinha é sempre contralto; os pobres têm a voz mais na frente (e imita estridentemente a voz); os ricos têm a voz mais arredondada (ri muito)” (Steves 2015: 155).

Ambos os intérpretes se referiam à função exercida pelas personagens na trama, independentemente do conteúdo: “a boazinha”, o "vilão”... Aspectos do comportamento, do temperamento e da moralidade das personagens - a princípio dependentes do trabalho de interpretação - alicerçavam a própria narrativa. Nos Estados Unidos, a conversa com uma estudante de teatro foi especialmente reveladora nesse sentido. Com cerca de $1,5 \mathrm{~m}$, cabelos escuros bastante encaracolados, olhos castanhos, 21 anos, autodenominada "caucasian", Nina, num intervalo da aula, declarou entre risos breves e um leve tom de deboche: "Eu acho que sou estranha. Se tiver uma fila de meninas [no palco], eu não vou me encaixar lá. Mas se você tiver uma [personagem] neurótica, tudo bem. Se você quiser maluca, eu posso ser a maluca”.

Sua fala despretensiosa me chamou atenção. $\mathrm{O}$ argumento articulava diversos elementos em poucas frases: corpo, aparência, emoção e personalidade. A partir de então, uma sequência de comparações foi concebida. Para afirmar "ser estranha", a jovem atriz fez referência a uma "normalidade" que não estava explícita. O exemplo aparece na frase seguinte, ao evocar a imagem de meninas em fila. Impossível determinar a que referencial, exato, ela aludia. Entretanto, o que fica evidente é que, para Nina, a diferença de seu corpo em relação à fila imaginária seria mais significativa do que as diferenças entre os corpos dessas atrizes. A sua “estranheza” parecia estar, até esse momento, associada a uma dimensão fenotípica.

12 Nascido em 1973, em Brasília, Vasconcelos é ator, cantor e dublador. Já fez mais de uma dezena espetáculos no Brasil.

$13 \mathrm{O}$ ator nasceu em Novo Hamburgo, no Rio Grande do Sul, em 1970 e, nos palcos, já esteve à frente de mais de vinte espetáculos. 
$\mathrm{Na}$ frase subsequente, contudo, Nina desloca o argumento do aspecto do seu corpo para característica de personalidade de uma personagem: poderia interpretar a "neurótica”. Nessa passagem, a atriz mobiliza sua habilidade de atuação como potencialidade. Se o fenótipo a desloca e desiguala, a destreza artística a distingue e diferencia. Ela operava a associação entre talhe e personalidade. Ao se classificar como "estranha", logo no início da fala, Nina talvez estivesse sugerindo se sentir diferente fisicamente e em termos de personalidade. De qualquer forma, no seu relato, a relação é direta: por ser estranha, não se encaixaria em uma situação na qual haveria um quesito de homogeneidade física e, ao mesmo tempo, isso lhe conferia a capacidade para também interpretar personagens cujo comportamento ela parecia situar como igualmente extraordinário.

Essas falas são indício de como o perfil não age exclusivamente no corpo; ele extrapola para o comportamento das personagens e interfere diretamente no trabalho de interpretação. A relação que se estabelece não é única e exclusivamente derivada da similitude externa, mas constituída a partir de paralelos ligados ao temperamento, à qualidade e ao valor. O corpo é tomado, assim, como o elemento de associação direta entre artista e personagem.

Essa convenção naturaliza a associação entre determinados corpos e certas ações. Segundo Luana me explicou, o seu corpo já continha muita informação "sem abrir a boca”. A aparência da personagem Bela era conhecida antes mesmo do início da produção do espetáculo, pois havia um repertório imagético que antecipava a própria seleção de atrizes. Sinais diacríticos presentes nos corpos de intérprete carregam histórias, significados, dores, violências, privilégios e afins. As experiências pregressas da família de Luana são indício da posição social que os seus ascendentes ocuparam — a mãe, neta de índios e holandeses, e o pai, descendente de portugueses e negros. Aos olhos de produtores, tais características físicas seriam necessariamente incongruentes com a posição "prestigiosa” de uma "princesa da Disney".

Desse modo, quando a convenção assume a classificação de pessoas com "cara de vilão", "cara de maluca", "cara de princesa" e afins, ela supõe a existência de um corpo pré-discursivo, no qual há uma associação imediata entre o fenótipo e as ações. Dentro dessa lógica, a inteligibilidade das personagens ficaria comprometida quando não estivesse assegurada a congruência entre os imaginários constituídos sobre elas e os corpos de suas/seus intérpretes. Sob os muros dessas instituições de ensino, o corpo era percebido como um testemunho do que seriam — social e historicamente - determinados grupos.

A convenção perfil, portanto, naturalizava os imaginários constituídos sobre corpos das pessoas e previa que a apresentação física de alguém poderia ser indício para inferir sua moral, suas escolhas individuais e suas ações futuras. Estudantes aprendiam como podiam interpretar personagens desde que seus corpos - e, naquele universo de valores, suas personalidades - lhes permitissem. Isto é, o "perfil" faz desse tipo de teatro um cúmplice do cerceamento profissional, imagético e ético de artistas e populações específicas.

Por fim, não havia nas disciplinas um espaço para acolhimento de dores ou angústias causadas pelos princípios do perfil e por seus efeitos. Os constrangimentos, quando surgiam no formato de silêncios e olhares, recebiam poucas luzes, permanecendo na penumbra. Professores não endereçavam o assunto e cabia às estudantes lidar com tais restrições. Luana dizia ter se conformado, Andressa evi- 
denciava um pragmatismo em assumir ser "o alívio cômico", as jovens brasileiras ironizavam os efeitos qualificando-se como "ogras" e Nina debochava chamando-se de "neurótica”.

\section{Considerações finais}

O processo de aprendizagem da convenção perfil em escolas de teatro musical em São Paulo e em Nova York guardava grande proximidade, apesar das diferenças entre as cidades e seus contextos. Tal continuidade revela a força da convenção e a necessidade de destrinchar suas características.

Como descrito e analisado, dentro dessa pedagogia dos corpos, o perfil exigia a coerência entre os traços fenotípicos da(o) intérprete e de sua personagem. Sob tal parâmetro eram atualizadas estruturas moralizantes de raça, gênero e sexualidade. Além disso, o critério servia para qualificar o valor de intérpretes no mercado de entretenimento. Tal aspecto estético instituía uma relação de congruência entre a personalidade $\mathrm{da}(\mathrm{o})$ artista e o temperamento da personagem. Como resultado, o perfil produzia fronteiras muito definidas e hierarquizantes entre os corpos de estudantes. Os corpos, independentemente das ações dos sujeitos, apareciam como portadores de valores a priori: beleza, força, elegância, inteligência e afins.

Por sinal, as formas de ensino dessas aulas foram determinantes para a sedimentação da noção de perfil nos corpos e nos comportamentos das estudantes. Em primeiro lutar, a convenção era aprendida aos poucos, tacitamente e sem grandes alardes. Em vez de frases categóricas como "você tem perfil de vilâ", preferia-se os incentivos elogiosos para quem já havia entendido as regras do jogo e as broncas para as situações em que estudantes se desviavam das prescrições — "é blush”, “é diva”.

Em segundo lugar, o teor imperativo das explicações e a ausência de espaço de acolhimento transformavam a sala de aula em um ambiente com pouca contestação, reflexão e crítica. Não presenciei, durante a pesquisa, discussões a respeito dos efeitos sociais e estéticos dessa prática. Somente nos momentos de intervalo e de descontração, estudantes encontravam brechas para ironizar, desabafar e indicar como aqueles parâmetros lhes interrompiam as possibilidades.

Em terceiro lugar, os exercícios de simulação ficcional de audições cumpriam um papel importante. Como o ato de interpretar era um valor em si - afinal, o objetivo de estudantes era a profissão de atriz/ator - tais exercícios lúdicos transformavam o processo de naturalização da diferença — via categoria perfil - em algo palatável. Para participar do jogo e aprender a se portar em uma audição, estudantes precisavam mobilizar seu perfil.

Por fim, o tom de coleguismo adotado por professores e suas anedotas dos bastidores produziam um efeito retórico: eles sugeriam estar quase na mesma posição que os estudantes, o que contribuía para embrulhar o conteúdo como se fosse a oferta de um segredo, um privilégio partilhado.

Se a relação entre antropologia e educação já possui pontos a serem discutidos e afinados, como os usos controversos da etnografia (Gusmão 1997; Pereira 2017), em contexto de escolas de teatro musical, os problemas se ampliam. Segundo Neusa Gusmão, o que está em questão na interação entre a antropologia e a educação diz respeito ao modo como elas lidam com a alteridade: "A aventura de se colocar no lugar do outro, de ver como o outro vê, de compreender um conhecimento que não é o 
nosso" (Gusmão 1997: 8). No caso das escolas de teatro, acrescentamos mais uma camada a ser explorada: trata-se de um ambiente pedagógico em que estudantes aprendem a atuar um outro. Estudantes de teatro musical aprendiam, em sala de aula, a identificar suas próprias características corporais para, então, realizar uma personagem, isto é, eram sujeitos que se constituíam dentro de um paradigma que previa a investigação de si para a execução de um outro via seu próprio corpo.

Além disso, as estratégias de ensino adotadas, mesmo quando se assemelham àquelas presentes em instituições formais, estão inseridas num contexto distinto e ganham outros significados a serem explorados. Tassinari (2015) evidencia como processos de ensino e de aprendizado ocorrem via práticas corporais, pela necessidade de produzir "corpos ativos". Nos ambientes de teatro musical em que fiz pesquisa havia uma valorização não só do "corpo ativo", mas também uma "centralidade do corpo" - sua apresentação, seus gestos, suas composições. Os corpos eram continuamente marcados, classificados e a eles eram atribuídos sinais de diferença e de valor.

Com este trabalho procurei realizar alguns apontamentos para aprofundar o debate a respeito da relação entre antropologia, educação e escolas de teatro. A meu ver, estas instituições podem oferecer uma entrada estimulante para as discussões sobre a relação intrincada entre processos de aprendizagem e as práticas de produção das diferenças.

\section{Bernardo Fonseca Machado é Doutor em Ciências Sociais (Antropologia So- cial) pela Universidade de São Paulo (USP) e pós-doutorando na Universidade de Campinas (Unicamp). Bolsista Fapesp, projeto no 2019/08713-2.}

\section{REFERÊNCIAS BIBLIOGRÁFICAS}

Alegria, Paula. 2018. “'Vai ter viado se beijando, sim!': gênero, Sexualidade e juventude entre alunos do movimento estudantil secundarista de uma escola pública federal do Rio de Janeiro". Teoria e Cultura 13(1): 36-50. doi: https://doi.org/10.34019/2318-101X.2018.v13.12395

Araújo, Carolina P. de. 2009. Ensaio sobre o ator: a criação de si e o aprendizado da atuação. Tese de Doutorado. Programa de Pós-graduação em Antropologia Social, Museu Nacional, Universidade Federal do Rio de Janeiro.

Bazzo, Juliane. 2017a. "A agência da noção de bullying no contexto brasileiro a partir da etnografia de uma experiência escolar". Horizontes Antropológicos 49 (3): 203-231. doi: https://doi.org/10.1590/ s0104-71832017000300008

Bazzo, Juliane. 2017b. "Da tortuosa elucidação do trágico: a agência da noção de bullying em meio a eventos extremos de violência juvenil”. Iluminuras 18 (44): 38-73. doi: https://doi. org/10.22456/1984-1191.75733 
Brah, Avtar. 2006. "Diferença, diversidade, diferenciação”. Cadernos Pagu 26(1): 329-365. doi: https://doi.org/10.1590/S0104-83332006000100014

Carneiro da Cunha, Manuela. 2009. “'Cultura' e cultura: conhecimentos tradicionais e direitos intelectuais”. Pp. 311-374 in Cultura com aspas e outros ensaios. São Paulo: Cosac \& Naify.

Carvalho, Marília Pinto de. 2004. "O Fracasso escolar de meninos e meninas: articulações entre gênero e cor/raça”. Cadernos Pagu 22: 247-290. doi: https://doi.org/10.1590/S010483332004000100010

Cesar, Rafael do Nascimento. 2018. "A fragata negra - tradução e vingança em Nina Simone”. Mana 24(1): 39-70. doi: https://doi.org/10.1590/1678-49442018v24n1p039

Cipiniuk, Tatiana Arnaud. 2014. "Etnografia em uma escola pública e seus desafios: um olhar sobre métodos aplicados no itinerário do trabalho de campo". Educere et Educare 17: 83-91. Disponível em: http://e-revista.unioeste.br/index.php/educereeteducare/article/view/10309. Acesso em 13 jan 2021.

Coelho, Maria Claudia. 1989. Teatro e contracultura: um estudo de antropologia social. Dissertação de Mestrado. Programa de Pós-Graduação em Antropologia Social, Museu Nacional, Universidade Federal do Rio de Janeiro.

Corrêa, Mariza. 2007. “Sobre a invenção da mulata”. Pp. 243-254 in Olhares Feministas, org. H.P. Melo et al. Brasília: Ministério da Educação, UNESCO.

Crenshaw, Kimberlé. 1991. "Mapping the margins: intersectionality, identity politics, and violence against women of color”. Stanford Law Review 43(6): 1241-1299. doi: https://doi. org/10.2307/1229039

Dauster, Tania. 2015. "Um diálogo sobre as relações entre etnografia, cultura e educação - representações e práticas”. Linhas Criticas 44(21): 39-56. doi: https://doi.org/10.26512/lc.v21i44.4465

Escoura, Michele. 2012. Girando entre princesas: performances e contornos de gênero em uma etnografia com crianças. Dissertação de Mestrado. Programa de Pós-Graduação em Antropologia Social, Universidade de São Paulo.

Fonseca, Claudia. 1999 “Quando cada caso não é um caso: pesquisa etnográfica e educação”. Revista Brasileira de Educação 10 (1): 58-78. Disponível em: http://www.lite.fe.unicamp.br/papet/2003/ ep145/revist.htm. Acesso em 13 jan 2021.

Gomes, Nilma Lino. 2005. "Educação e relações raciais: refletindo sobre algumas estratégias de atuação". Pp. 143-154 in Superando o Racismo na escola, org. K. Munanga. 2 ed. Brasil: Ministério da Educação, Secretaria de Educação Continuada, Alfabetização e Diversidade. 
Gonzalez, Lélia. 1983. "Racismo e sexismo na cultura brasileira”. Ciências Sociais Hoje 2: 223-244.

Gusmão, Neusa Maria M. de. 2015. "Antropologia e educação: um campo e muitos caminhos" Linhas Criticas 44(21): 19-37. doi: https://doi.org/10.26512/lc.v21i44.4463

Gusmão, Neusa Maria M. de.1997. “Antropologia e educação: origens de um diálogo”. Cadernos Cedes 43: 8-25. doi: https://doi.org/10.1590/S0101-32621997000200002

Hirano, Luis Felipe. 2013. “O imaginário da branquitude à luz da trajetória de Grande Otelo: raça, persona e estereótipo em sua performance artística”. Afro-Ásia 48: 77-125. doi: http://dx.doi. org/10.1590/S0002-05912013000200003

Hirano, Luis Felipe. 2015. "O olhar oposicional e a forma segregada: raça, gênero, sexualidade e corpo na cinematografia hollywoodiana e brasileira (1930-1950)". Aceno 3(2): 142-158. Disponível em: https://periodicoscientificos.ufmt.br/ojs/index.php/aceno/article/view/2646. Acesso em 13 jan 2021.

Junqueira. Rogério D. 2010. “'A homofobia não é um problema. Aqui não há gays nem lésbicas!' Estratégias discursivas e estados de negação da discriminação por orientação sexual e identidade de gênero nas escolas". Revista de Psicologia da Unesp 9 (1): 123-139. Disponível em: https://seer.assis. unesp.br/index.php/psicologia/article/view/448. Acesso em 13 jan 2021.

Lave, Jean. 2015. “Aprendizagem como/na prática”. Horizontes Antropológicos 44: 37-47. doi: https:// doi.org/10.1590/S0104-71832015000200003

Macedo, Renata G. M. 2019. Escolhas possiveis: narrativas de classe e gênero no ensino superior privado. Tese de Doutorado. Programa de Pós-Graduação em Antropologia Social, Universidade de São Paulo.

Machado, Bernardo F. 2018. Atos da diferença: trânsitos teatrais entre São Paulo e Nova York no início do século XXI. Tese de Doutorado. Programa de Pós-Graduação em Antropologia Social, Universidade de São Paulo.

Machado, Bernardo F. 2019. "Intérpretes de masculinidades: estratégias de jovens atores para realizar seus personagens”. Pp 134-153 in Marcadores sociais das diferenças: fluxos, trânsitos e interseç̧ões, org. L.F. Hirano, M. Acuña e B. F. Machado. Goiânia: Editora Imprensa Universitária.

Machado, Bernardo F. 2020a. "Interpreters of difference: 'universal' communication and the national body of brazilian artists in the USA". Vibrant Virtual Braz. Anthr. 17: e17703. doi: https://doi. org/10.1590/1809-43412020v17d703

Machado, Bernardo F. 2020b. "Social Experience and US Musical Theatre on São Paulo's stages". Sociologia \& Antropologia. 10(3): 957-980. doi: https://doi.org/10.1590/2238-38752020v1038 
Miranda, Ana Paula M. de e Bóris Maia. 2017. “Olhares, xingamentos e agressões físicas: a presença e a (in)visibilidade de conflitos referentes às relações de gênero em escolas públicas do Rio de Janeiro". Horizontes Antropológicos 49(23): 177-202. doi: https://doi.org/10.1590/s010471832017000300007

Moutinho, Laura. 2004. Razão, "cor" e desejo: uma análise comparativa sobre relacionamentos afetivo-sexuais “inter-raciais” no Brasil e na África do Sul. São Paulo: Fundação Editora Unesp.

Moutinho, Laura. 2014. "Diferenças e desigualdades negociadas: raça, sexualidade e gênero em produções acadêmicas recentes". Cadernos Pagu 42(1): 201-248. doi: https://doi.org/10.1590/01048333201400420201

Pereira, Alexandre Barbosa. 2017. “Do controverso 'chão da escola' às controvérsias da etnografia: aproximações entre antropologia e educação". Horizontes Antropológicos 49(23): 149-176. doi: https://doi.org/10.1590/s0104-71832017000300006

Piscitelli, Adriana. 2008. "Interseccionalidades, categorias de articulação e experiências de migrantes brasileiras". Sociedade e Cultura 11(2): 263-274. doi: https://doi.org/10.5216/sec.v11i2.5247

Piscitelli, Adriana. 2011. "Amor, apego e interesse: trocas sexuais, econômicas e afetivas em cenários transnacionais". Pp. 537-582 in Gênero, sexo, amor e dinheiro: mobilidades transnacionais envolvendo o Brasil, org. A. Piscitelli, G.O. Assis \& J.M. Olivar. Campinas: Coleção Encontros Pagu/Núcleo de Estudos de Gênero UNICAMP.

Peres, Angela D. 2013. Entre o querer ser e o tornar-se: um estudo etnográfico sobre aspirantes à carreira de ator de televisão. Dissertação de Mestrado. Programa de Pós-Graduação em Antropologia Social, Museu Nacional, Universidade Federal do Rio de Janeiro.

Pontes, Heloisa. 2010. Intérpretes da Metrópole: História Social e relações de gênero no teatro e no campo intelectual, 1940-1968. São Paulo: EDUSP.

Ratts, Alex. 2016. “Corporeidade e diferença na geografia escolar e na geografia da escola: uma abordagem interseccional de raça, etnia, gênero e sexualidade no espaço educacional”. Terra Livre 31 (1): 114-141. Disponível em: https://www.agb.org.br/publicacoes/index.php/terralivre/article/ view/680. Acesso em 13 jan. 2021.

Ribeiro, Andrea R. 2008. Criação de sujeitos e identidades em uma escola de teatro: um estudo antropológico. Tese de Doutorado. Programa de Pós-Graduação em Antropologia Social, Museu Nacional, Universidade Federal do Rio de Janeiro.

Sedgwick, Eve K. 2007. “A Epistemologia do Armário”. Cadernos Pagu 28: 19-54. doi: https://doi. org/10.1590/S0104-83332007000100003. 
Silva, Cármen D. et al. 1999. "Meninas bem-comportadas, boas alunas; meninos inteligentes, indisciplinados". Cadernos de Pesquisa 107: 207-225. doi: https://doi.org/10.1590/S010015741999000200009 .

Sobral, Luís Felipe. 2015. Bogart duplo de Bogart: pistas da persona cinematográfica de Humphrey Bogart, 1941-1946. São Paulo: Terceiro Nome.

Steves, Gerson da Silva. 2015. A Broadway não é aqui: Panorama do Teatro Musical no Brasil. São Paulo: Giostri.

Tassinari, Antonella. 2015. "Produzindo corpos ativos: a aprendizagem de crianças indígenas e agricultoras através da participação nas atividades produtivas familiares”. Horizontes Antropológicos 44: 141-172. doi: https://doi.org/10.1590/S0104-71832015000200007.

Tosta, Sandra Pereira. 2013. "Antropologia e educação: interfaces em construção e as culturas na escola”. Revista Inter-Legere 9(1): 234-252. Disponível em: https://periodicos.ufrn.br/interlegere/ article/view/4415. Acesso em 13 jan. 2021.

\section{DOCUMENTOS}

Bureau of Labor Statistics. Usual weekly earnings of wage and salary workers, second quarter 2018. U. S. Department of Labor. 17 jul. 2018.

Reportagem Local. 2005. “Desgaste é 'sobre-humano', diz o Fantasma brasileiro”. Folha de S. Paulo, 20 abr. 2005. Ilustrada: E3. 
Resumo: Este artigo descreve aulas de "audição" de duas escolas de teatro musical - uma em São Paulo e outra em Nova York. O texto pretende, de um lado, adensar a discussão sobre um ambiente pedagógico ainda pouco explorado pela literatura da antropologia da educação: as escolas de teatro. E, de outro, analisar as práticas de ensino adotadas. Para isso, persigo os usos da categoria "perfil" nas salas de aula e nas falas de docentes e de estudantes. Tal categoria, fundamental no vocabulário desses ambientes, confere acesso para discutir sistemas de classificação que hierarquizam corpos e atualizam normativas de gênero, sexualidade e raça no cotidiano pedagógico. Com base em pesquisa de campo e em entrevistas, procurei responder as seguintes perguntas: como se aprende o "perfil”? Como essa convenção produz diferenças e desigualdades nos corpos de estudantes?

Palavras-chave: corpos; sistemas de classificação; perfil; escolas de teatro musical; formas de ensino.

\title{
USES OF TYPECAST - FORMS OF TEACHING AND PRACTICES OF DIFFERENCE IN MUSICAL THEATER SCHOOLS
}

\begin{abstract}
This article describes "audition" classes at two musical theater schools - one in São Paulo and other in New York City. The text intends, on one hand, to broaden the discussion about a pedagogical environment still little explored by the literature of the anthropology of education: theater schools. And, on the other hand, to analyze the teaching practices adopted. To do that, I follow the uses of the category "type" during classes and in teachers' and students' speeches. This category, fundamental in these environment vocabularies, gives access to discuss classification systems that hierarchize bodies and update norms of gender, sexuality, and race in daily teaching. Based on field research and interviews, I tried to answer the following questions: how people learn about their typecast? How does this convention produce differences and inequalities in students' bodies?
\end{abstract}

Keywords: bodies; classification systems; type; musical theater schools; teaching forms.

RECEBIDO: $31 / 05 / 2020$

APROVADO: $22 / 12 / 2020$ 